\title{
Generalised nevus flammeus, episcleral capillary malformation and glaucoma
}

\author{
Brijesh Takkar, ${ }^{1}$ Harsha Saxena, ${ }^{1}$ Bhavana Sharma, ${ }^{1}$ Anubha Rathi ${ }^{2}$
}

${ }^{1}$ Department of Ophthalmology, All India Institute of Medical Sciences, Bhopal, India ${ }^{2}$ Dr Rajendra Prasad Centre for Ophthalmic Sciences, All India Institute of Medical Sciences, New Delhi, India

\section{Correspondence to}

Dr Anubha Rathi,

ana.aiims@gmail.com

Accepted 9 October 2018

\section{DESCRIPTION}

A 35-year-old woman presented with no vision, redness, pain and photophobia in the left eye (LE) since 4 months. This was associated with left-sided headache and vomiting too. She had history of poor vision in LE since $2-3$ years, and had been treated with topical antiglaucoma medication. There was no significant family history. On examination, visual acuity was 6/6 in right eye (RE) and no perception of light in LE. Intraocular pressure (IOP) was measured as $14 \mathrm{~mm} \mathrm{Hg}$ in $\mathrm{RE}$ and $>60 \mathrm{~mm} \mathrm{Hg}$ in LE. Slit lamp evaluation revealed conjunctival congestion, corneal oedema, fully dilated pupil and white cataract in LE (figure 1). Gonioscopy was within normal limits. RE ocular examination did not reveal any significant anomaly. RE pupil did not show any consensual response, while LE pupil was

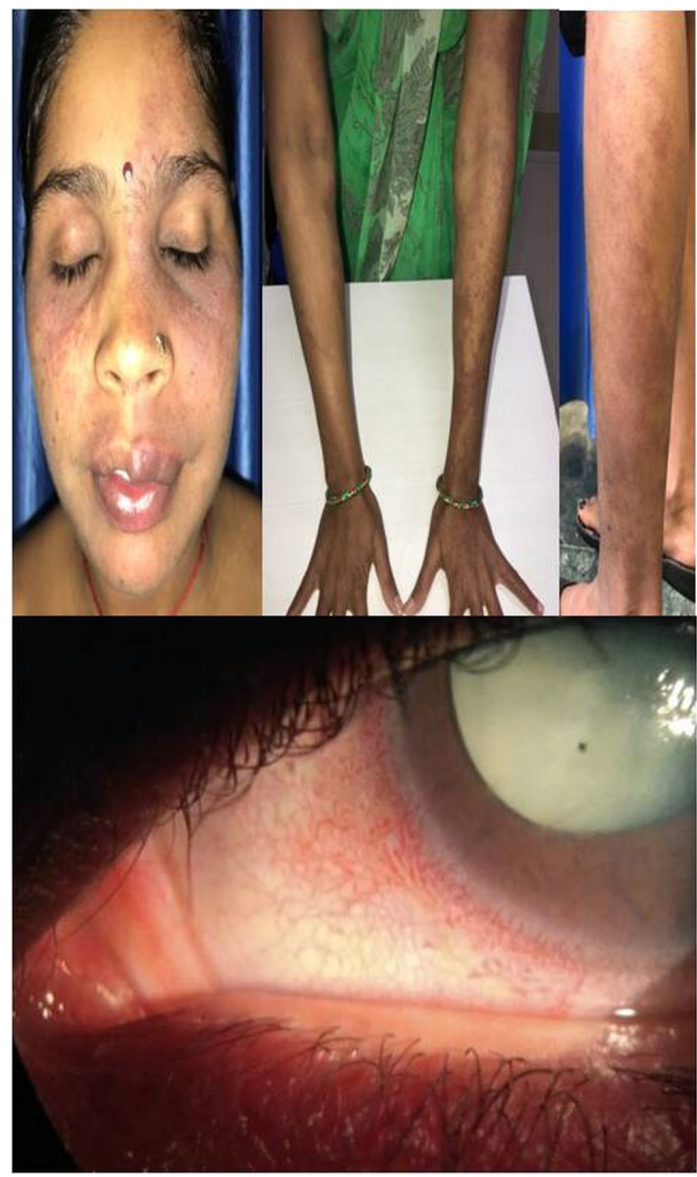
Limited 2018. No commercial re-use. See rights and permissions. Published by BMJ.

To cite: Takkar B, Saxena $\mathrm{H}$, Sharma B, et al. BMJ Case Rep Published Online First: [please include Day Month Year]. doi:10.1136/bcr-2018227248
Figure 1 Upper half of the figure shows nevus flammeus to be present on the face, upper limbs and lower limb. The lesions are more prominent over the left side of the body. Lower half of the figure shows the perilimbal episcleral capillary malformation and total cataract in the left eye. fixed. Systemic workup revealed nevus flammeus (NF) over the face involving both periocular regions but more prominent on the left side. Further examination showed the NF to be present all over the body (trunk and limbs), and was more prominent over the left side. The capillary malformation was dark purple in colour and non-blanchable to external pressure. Plaque-like changes and underlying soft tissue hypertrophy were noticeable in some areas (figure 1). No other pigmentary changes were seen. On closer ocular examination, the episcleral capillaries around the limbus were found to be engorged, with telangiectasia and focal bulbous dilations (figure 1).

The patient was diagnosed to have a generalised NF with end-stage glaucoma in LE. Hyperosmotic agents and oral acetazolamide were advised while the systemic workup proceeded. Ultrasound of the LE revealed an anechoic vitreous cavity and no signs of choroidal tumours. No anomalies were detected on radioimaging of head, chest and abdomen. She was also evaluated by a dermatologist, physician and gynaecologist, but no other systemic anomalies were found. A $270^{\circ}$ transconjunctival cryoablation of the ciliary body was done, and 15 days following the procedure the IOP was $18 \mathrm{~mm} \mathrm{Hg}$ on a topical combination of dorzolamide and timolol. As the patient was asymptomatic only on topical medication, further surgical interventions were deferred.

NF, also called port wine stain, is a capillary malformation well known to involve the head and neck area. The capillary ectasia may be progressive. Syndromic involvement is well known in the form of Klippel-Trenaunay syndrome, Sturge-Weber syndrome, Cobb syndrome, Proteus syndrome, Rubinstein-Taybi syndrome and others. ${ }^{1}$ It may simulate vascular tumours in infancy or young children. Glaucoma is also a well-documented association, and may be seen in as much as one-fifth of these eyes. ${ }^{2}$ The causes include raised episcleral venous pressure due to the capillary malformation, associated intraocular tumours and angle anomalies. A large number of such eyes, close to half, need surgical procedures including cyclodestruction for IOP control as done in our case. ${ }^{2}$

Capillary malformations may be classified depending on whether they represent naevi or not. ${ }^{3}$ NF is believed to be a type of malformation representing naevi. It can be generalised and involve the rest of the body apart from the face, and can also have predilection for involvement of one side of the body only. While generalised NF is known to be associated with glaucoma as a part of syndromes or phacomatoses like phacomatosis pigmentovascularis, solitary ocular involvement with generalised NF is rare. 


\section{Learning points}

Generalised port wine stain can occur with glaucoma in absence of systemic anomalies. However, systemic involvement must be ruled out as a multidisciplinary approach.

- Cyclodestruction remains a useful technique for managing such painfully blind eyes with absolute glaucoma.

Contributors BT and HS worked up, performed imaging and diagnosed the patient. BT and BS managed the patient. All authors wrote the manuscript. AR critically revised the text.
Funding The authors have not declared a specific grant for this research from any funding agency in the public, commercial or not-for-profit sectors.

Competing interests None declared.

Patient consent Obtained.

Provenance and peer review Not commissioned; externally peer reviewed.

\section{REFERENCES}

1 Lee JW, Chung HY, Malformations C. Capillary Malformations (Portwine Stains) of the Head and Neck: Natural History, Investigations, Laser, and Surgical Management. Otolaryngol Clin North Am 2018:51:197-211.

2 Khaier A, Nischal KK, Espinosa M, et al. Periocular port wine stain: the great ormond street hospital experience. Ophthalmology 2011;118:2274-8.

3 Happle R. Capillary malformations: a classification using specific names for specific skin disorders. J Eur Acad Dermatol Venereol 2015;29:2295-305.

Copyright 2018 BMJ Publishing Group. All rights reserved. For permission to reuse any of this content visit

http://group.bmj.com/group/rights-licensing/permissions.

BMJ Case Report Fellows may re-use this article for personal use and teaching without any further permission.

Become a Fellow of BMJ Case Reports today and you can:

- Submit as many cases as you like

Enjoy fast sympathetic peer review and rapid publication of accepted articles

- Access all the published articles

Re-use any of the published material for personal use and teaching without further permission

For information on Institutional Fellowships contact consortiasales@bmjgroup.com

Visit casereports.bmj.com for more articles like this and to become a Fellow 